\title{
Issues and challenges influencing school improvement opportunities for science and mathematics
}

Maria Tsakeni $^{\text {* }}$, University of the Free State, School of Mathematics, Faculty of Education, Natural Sciences and Technology Education, Private Bag X13, Phuthaditjhaba, 9866, South Africa https://orcid.org/0000$\underline{0003-3208-1362}$

Paul Munje ${ }^{b}$, Univeristy of the Free State, School of Education, Faculty of Education, P.O. Box 339, Bloemfontein, 9300, South Africa https://orcid.org/0000-0002-7948-9704

Loyiso Jita c, University of the Free State, Faculty of Education, P.O. Box 339, Bloemfontein, 9300, South Africa https://orcid.org/0000-0001-6871-6820

\section{Suggested Citation:}

Tsakeni, M., Munje, P. \& Jita, L., (2021). Issues and challenges influencing school improvement opportunities for science and mathematics. Cypriot Journal of Educational Science. 16(3), 1300-1318. https://doi.org/10.18844/cjes.v16i3.5853

Received from January 11, 2021; revised from Apirl 15, 2021; accepted from June 16, 2021.

${ }^{\circ} 2021$ Birlesik Dunya Yenilik Arastirma ve Yayincilik Merkezi. All rights reserved.

\begin{abstract}
This qualitative interpretive study explores issues and challenges influencing school improvement opportunities for Science and Mathematics in selected South African high schools through a systems leadership lens. Unstructured interviews were conducted with 13 participants comprising a principal, deputy principals, heads of department (HODs) for Science and Mathematics, and Mathematics and Physical Sciences teachers in four schools. The data from the interviews were analysed using the constant comparison techniques, allowing for inductive theme and concept building through abstraction. Findings show that participants, irrespective of school context, were generally eager to enhance the teaching and learning of Science and Mathematics. These challenges include the curriculum policy, the role of the district education office, professional development, learner-related challenges, and resources. It is recommended that the Department of Basic Education work closely with the relevant stakeholders, including teachers, to ensure context-friendly educational policies, thus ameliorating implementation challenges.
\end{abstract}

Keywords: Issues and challenges, Science and Mathematics, school improvement, systems leadership;

* AdDRESS FOR CORRESPONDENCE: Maria Tsakeni, University of the Free State, Private Bag X13, Phuthaditjhaba, 9866, South Africa

E-mail address: mtsakeni@gmail.com/tsakenim@ufs.ac.za / Tel.: +27-58-718-5001 


\section{Introduction}

Factors affecting school improvement are likely to differ between urban, suburban, and rural schools (Dolph, 2017). Donaldson and Weiner (2017, p. 65) described these factors as "... difficult, context-specific, and incremental". In South Africa, low levels of learner performance in Science and especially Mathematics in some contexts are raising concerns (Gaillard, 2019; Venkat, Askew, Morrison \& Abdulhamid, 2019), requiring exploration to understand existing challenges to pave the way for improvement. In South Africa, poor teaching is associated with the poor quality of teachers, which Murray (2016) contended is associated with school quality, that schools with lower income are more likely to appoint less qualified teachers. School challenges are classified in two categories, external and internal.

On looking at external challenges to school improvement, educational policies (Leithwood, Harris \& Hopkins, 2020) and the nature of district intervention are likely to affect school improvement efforts. Changes in curriculum reforms across the globe create curriculum-implementation challenges for teachers (Supovitz, D’Auria \& Spillane, 2019; Taahayadin, \& Daud, 2018). The overwhelming argument is that the political elite, with limited practical educational experiences, overshadow the design of educational policies (Govender, 2008; Makoelle, \& Sabata, 2019; Molapo, \& Pillay, 2018; Moswela, \& Kgosidialwa, 2019). This creates gaps between policy and practice because policy designers do not consider contextual realities in individual schools, resulting in teachers being caught between contextual realities and policy expectations during implementation (Bayeni, \& Bhengu, 2018). Grounded in these allegations, teachers refute claims that poor learner performance resonates from the poor quality of teachers and teaching (Mouton, Louw \& Strydom, 2013; Thaba-Nkadimene, \& Mmakola, 2019). Teachers disagree with headlines openly blaming the woes of South Africa's education system on them (Robinson, 2019). Still, Leoisa and Jita (2020) argued that teacher interpretation of policy tenets is also to blame for implementation challenges.

Although district officials play phenomenal roles in enhancing curriculum implementation (Bantwini, \& Diko, 2011), their visibility (Bantwini, \& Moorosi, 2018a) and lack of follow-ups are under criticism (Taole, 2013). They are criticised for poor responses to challenges identified or raised by schools. Hence, educators do not receive the necessary support (Nkambule, \& Amsterdam, 2018), with implications on instruction and learner performance (Dagnew, 2017). Although circuit managers are expected to be constantly in contact with schools and teachers, Bantwini and Moorosi (2018b, p. 4) described them as "the weakest link" in the administrative chain at the district level. Inadequate support from them impedes school improvement efforts, a phenomenon Du Plessis and Mestry (2019) argued is peculiar to rural schools, which are unlikely to be visited by district officers. However, Bantwini and Moorosi (2018b) contended that the shortage of circuit managers in some parts of the country creates a huge burden leading to inadequate service delivery. Additionally, rural schools are often located far apart, making visitations by circuit managers challenging (Bantwini, \& Moorosi, 2018b; Nkambule, \& Amsterdam, 2018).

The internal challenges relate to the context-specific challenges that affect teachers' abilities to enhance school improvement (Bush, \& Glover, 2016) which include professional development, teacher-specific challenges, and resources. The lack of opportunities for teacher professional development negatively affects school improvement (Molapo, \& Pillay, 2018). Professional development opportunities in some instances are insufficient and/or of low quality, or do not meet the needs of the trainees (Jacobs, Gordon \& Solis, 2016). These scenarios are attributed to inadequate capacitation of district officials (Bantwini, \& Diko, 2011) who provide such services, in turn leading to 
poor or inadequate teacher capacitation, which increases challenges in schools (Aldaihani, 2020). Inadequate teacher capacitation impedes the enhancement of teaching and learning opportunities (Dagnew, 2017; Nkambule, \& Amsterdam, 2018). As such, Brunetti, Büchel, Jakob, Jann, Kühnhanss and Steffen (2020) contended that low-quality education in developing countries is linked to teacher capacitation in terms of content knowledge. They described this trend as worrisome and needing attention, especially in an era when many African countries are pursuing the quality-education agenda.

Likewise, teachers face individual challenges that obstruct efforts to enhance teaching and learning in Science and Mathematics. It is argued that teacher individual engagement with lesson planning (Naicker, \& Mestry, 2013), excessive workload (also see Ogegbo, Gaigher \& Salagaram, 2019; Taole, 2013) and the lack of/or inadequate professional development opportunities hinder teachers' ability to enhance teaching and learning of Science and Mathematics. Workload, including teaching and administrative duties, reduces the time required by HODs to perform their duties of monitoring and supporting instruction (Jacobs, Gordon \& Solis, 2016; Matsepe, \& Maluleke, 2019). Additionally, inadequate school resources have impeded attempts by schools to enhance teaching and learning (Dagnew, 2017; Molapo, \& Pillay, 2018; Ogegbo, Gaigher \& Salagaram, 2019; Supovitz, D’Auria \& Spillane 2019), a phenomenon peculiar to disadvantaged schools (Waller, \& Maxwell, 2017). For example, despite their potential of transforming the learning environment, educational technologies are scarce in disadvantaged schools (Daya, \& Laher, 2020). Their lack thus poses teaching and learning challenges, especially in Science and Mathematics (De Freitas, \& Spangenberg, 2019).

Furthermore, the lack of capacitation prevents some teachers from integrating technology in Science and Mathematics classrooms, a challenge Dixon (2020) considered renowned in South Africa. Lack of access to and poor maintenance of available resources, insufficient internet access, insufficient data packages, and limited bandwidth contribute to hinder technology integration in some school contexts (Waller, \& Maxwell, 2017). Besides this, there is evidence of wastage or underutilisation of public resources in some schools (Brunetti, Büchel, Jakob, Jann, Kühnhanss \& Steffen, 2020), thus impeding on teaching and learning opportunities. Such scenarios are challenging for teachers with the zeal to integrate technology in the classroom (Mwapwele, Marais, Dlamini \& Van Biljon, 2019, hence the need to mitigate such challenges to enhance school improvement.

\subsection{Research Problem}

Science and mathematics education is characterized by learner under-achievement in most secondary schools. The under-achievement threatens a considerable number of school improvement plans after taking into account that schooling is managed under high stakes testing environments. At the same time science and mathematics teaching and learning fall under the national programs of STEM education that are seen as a pathway to economic growths, job creation and technological advancements for countries (Clothey, Mills \& Baumgarten, 2010). On the one hand, science and mathematics education, and learner achievement are influenced by school contextual factors in addition to the historical and socio-economic factors resulting in unique school improvement pathways for schools (Hallinger \& Heck, 2010). On the other hand, learner achievement is closely related to school improvement plans which are in turn guided by school leadership. School leadership is very essential to teaching and learning and therefore in this study, systems leadership was used to explore school improvement opportunities for science and mathematics as influenced by contextual factors in some selected South African schools. 


\subsection{Research Focus}

The study focus is located in the area of school improvement through the teaching and learning of science and mathematics. The study also falls under the area of school leadership for science and mathematics in particular.

\subsection{Research aim and questions}

This study explores the issues and challenges influencing school improvement opportunities for Science and Mathematics in selected high schools of South Africa. The study addressed the question, what are the issues and challenges influencing school improvement opportunities for Science and Mathematics in selected high schools of South Africa? A systems leadership lens was used as a filter to explore the issues and challenges that influence the school improvement opportunities.

\section{Theoretical Framework}

This paper is underpinned by the systems leadership framework for school improvement, whereby a confluence of factors within specific contexts combines to influence school improvement. Heffernan (2018) emphasised the importance of considering contextual realities holistically to ensure effective curriculum implementation. The contextual factors are at three levels, namely, the school and community, the school districts and the national educational policies (Fullan, 2005). These levels served as topics that guided the unstructured interviews that were used to collect data. Therefore, identifying and resolving contextual challenges become the main goal of effective school leadership to ensure school improvement (Marishane, 2016; Mowat, 2019). Successful leaders are context-sensitive when they enact educational policies (Heffernan, 2018; Leithwood, Harris \& Hopkins, 2020; Sebastian, Huang \& Allensworth, 2017). This ensures effective curriculum implementation, even when schools encounter a multitude of challenges, such as inadequate school resources, socioeconomic challenges, and parental non-involvement (Dolph, 2017; Leithwood, Harris \& Hopkins, 2020).

Furthermore, successful schools prioritise ongoing professional development for novice school leaders to provide the skills necessary for effective curriculum implementation and the achievement of school improvement agendas (Liljenberg, \& Wrethander, 2020; Marishane, 2016). For Liljenberg and Wrethander (2020), to ensure skills maximisation, professional development opportunities can have an impact if the content of the training is aligned with the daily needs of novice school leaders in particular and those of the individual schools in general. This practical approach to training, which is capacity-building orientated, responds to contextual needs and has positive implications for school improvement (Marishane, 2016). Additionally, effective school leaders encourage collaboration (Mowat, 2019) and create a motivational working environment for all teachers (Marishane, 2016).

The importance of context-conscious school leaders resonates in Dolph's (2017) study, which identifies urban schools as having a multitude of challenges, including poverty, which negatively affect teaching and learning. Dolph (2017) also noted that a majority of these learners are from single parent households and likely to exhibit disciplinary problems in the classroom, thus often needing professional attention and parental involvement. Besides, Shaked and Schecther (2020) from the systems thinking approach recommended that school principals should think about school improvement from a holistic manner, based on the complexities involved in each school context. Sebastian, Huang and Allensworth (2017) noted that external factors such as educational policies impede curriculum-delivery efforts. As such, effective leaders need to always assess the challenges they pose and address them to ensure successful school improvement agendas. 


\section{Methods and context}

This is a qualitative interpretive multi-case study (Yin, 2018) involving four secondary schools that focused on improving Science and Mathematics. In identifying the schools, we used Mitchell and Sackney's (2016, p. 857) criteria for identifying high-impact schools. The criteria comprise the following characteristics: "(1) evidence of high energy and enthusiasm across the school; (2) a reputation for high quality in teaching and learning; (3) a collaborative culture among the staff; (4) innovation and experimentation in pedagogy and curriculum; (5) reflective practices among the educators; (6) authentic community involvement; and (7) a record of improved student learning outcomes Therefore, using purposive sampling based on this school improvement agenda, we selected two former model C schools (Schools A and B), composed of multi-racial learner populations, and two township schools (Schools $C$ and D), consisting of learners from African cultural backgrounds. Former model $\mathrm{C}$ schools in South Africa are schools that were formerly attended only by White learners before the new political dispensation of 1994 (Selod, \& Zenou, 2003).

\subsection{Sample}

The school improvement plans for Science and Mathematics in the selected schools were based on a formerly government-funded nationwide programme of Dinaledi schools. The four schools could be grouped into two socioeconomic strata, with Schools A and B located in a middle-income neighbourhood of Pretoria South, and Schools $C$ and D located in a low income neighbourhood of Pretoria West. Purposive sampling was used to select schools from middle- and low-income neighbourhoods to allow for triangulation of the issues and challenges that affected school improvement opportunities for Science and Mathematics based on the differing contexts. However, convenience sampling was used to select the participants from each school who were identified by the school leadership. The researchers had however indicated that they would like to interview individuals who actively participated in the school leadership for science and mathematics improvement. From the summary of participants in Table 1 it could be noticed that the heads of department in Schools $C$ and $D$ were for both science and mathematics whilst Schools $A$ and $B$ had heads of department for science and mathematics separately. This is a manifestation of how resource allocation differ across schools as determined by the socio-economic status.

Table 1. Summary of participants per school

\begin{tabular}{|c|c|c|}
\hline School & School context & Participants \\
\hline A & $\begin{array}{l}\text { Middle-income socio- } \\
\text { economic status }\end{array}$ & $\begin{array}{l}\text { Principal } \\
\text { Science Head of Department } \\
\text { Mathematics Teacher }\end{array}$ \\
\hline B & $\begin{array}{l}\text { Middle-income socio- } \\
\text { economic status }\end{array}$ & $\begin{array}{l}\text { Science Head of Department } \\
\text { Mathematics Teacher } \\
\text { Physical Sciences Teacher }\end{array}$ \\
\hline C & $\begin{array}{l}\text { Low-income socio- } \\
\text { economic status }\end{array}$ & $\begin{array}{l}\text { Deputy Principal } \\
\text { Science Head of Department } \\
\text { Physical Sciences Teacher } \\
\text { Deputy Principal }\end{array}$ \\
\hline D & $\begin{array}{l}\text { Low-income socio- } \\
\text { economic status }\end{array}$ & $\begin{array}{l}\text { Science Head of Department } \\
\text { Mathematics Teacher } \\
\text { Physical Sciences Teacher }\end{array}$ \\
\hline
\end{tabular}




\subsection{Sample}

The use of the interpretive multi-case study and unstructured interviews, which were loosely guided by the selected topic of issues and challenges influencing the school improvement opportunities for science and mathematics, allowed us to engage in an interactive dialogue with participants through intermingling, asking questions, probing, listening and writing, and audiorecording data (Kivunja, \& Kuyini, 2017). The unstructured interviews lasted approximately an hour each and were conducted with each of the 13 participants describe in Table 1 . The data collection tool was loosely guided by Fullan (2005)'s levels of systems leadership as shown in Table 2.

Table 2. Example of data collection tool and coding

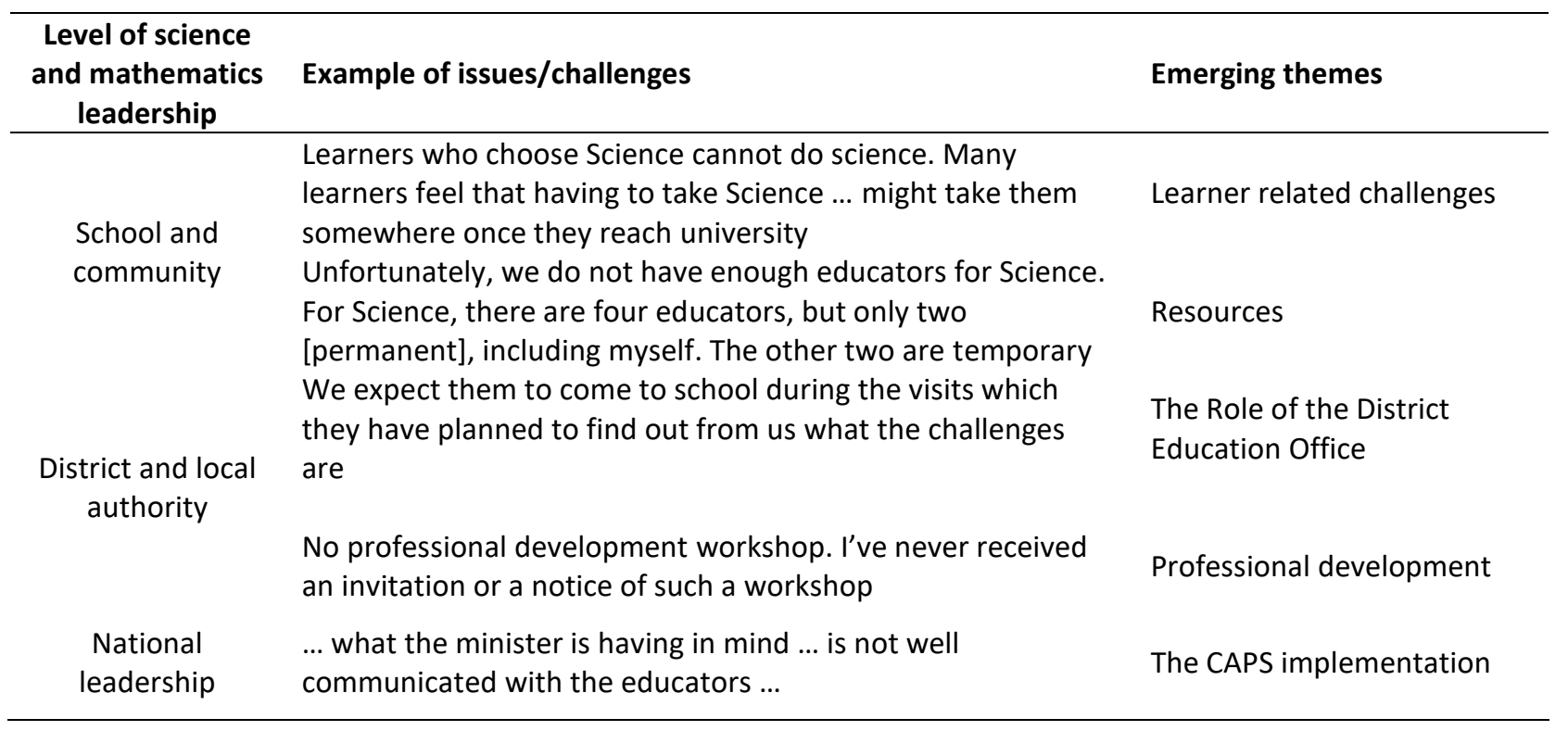

\subsection{Data Analysis}

As the findings are discussed in the next section, the participants are referred to by their designations and job description in each of the schools. For example, deputy principal from School $A$ will be referred to as School A's deputy principal. The participants were recommended by the schools as those who would best provide the necessary data for the study. The issues and challenges were explored using a systems leadership lens as an influencer of science and mathematics school improvement. It was assumed that science and mathematics improvement is influenced by school leaders, including teachers and other external stakeholders, thereby taking a holistic approach of looking at contextual factors. The data from the interviews were analysed using the constant comparison techniques that allowed comparing data from the four schools, and inductive theme and concept building through abstraction (Gawlik, 2015).

\subsection{Validity and reliability}

Content validity was ensured by using the three levels of systems leadership by Fullan (2005) as topics that guided the unstructured interviews with the participants. The use of unstructured techniques was also a way of enhancing content validity as participants shared all that they thought were issues and challenges without being restricted. Validity was ensured by collecting data from 4 different schools and the use of both high-income and low-income environments to achieve triangulation. 


\section{Findings of the study}

Five major themes defining the issues and challenges hindering school improvement emerged from the findings. These are (1) CAPS; (2) the role of the district education office; (3) professional development; (4) learner related challenges; and (5) resources.

\subsection{The Curriculum and Assessment Policy Statement Implementation}

Findings indicate that the conceptualization of CAPS contributes to challenges experienced by teachers. Participants linked the disjuncture between policy and practice to the non-involvement of teachers in policy-design processes. School C's Mathematics and Science HOD said: "The big challenge, I can say, it's from people who are developing the curriculum ... I don't think teachers are consulted, especially when there are some changes to be done in the curriculum itself."

Changes in educational policies are considered a major challenge to curriculum implementation (Sebastian, Huang \& Allensworth, 2017; Tapala, Van Niekerk \& Mentz, 2020), creating a disjuncture between what policies expect and contextual realities in schools. Participants attribute this to the politicisation of educational policies, limiting teacher participation, despite their eagerness to contribute towards effecting relevant changes (see Moswela, \& Kgosidialwa, 2019; Swanepoel, 2009). Participants described the CAPS document as a ministerial imposition on teachers. They were neither properly involved in communication nor adequately prepared for implementation. School C's Mathematics and Science HOD lamented:

... what the minister is having in mind ... is not well communicated with the educators ... consulting [with] teachers can help ... Not that we should be [telling them or] shall tell them what to do, but whatever they do, let them communicate and prepare [us] properly.

Bayeni and Bhengu (2018) suggested that the involvement of stakeholders, including teachers, in the formulation of educational policies can help resolve ongoing challenges related to policy implementation. Additionally, School C's Mathematics and Science HOD argued that the introduction of new policies by different ministers are part of the problem: "If you can recall, we had different ministers of education and each one of the ministers came with his approach or maybe we had NCS [national curriculum statement] and now we are having CAPS ... So that, that's the challenge there ..."

Participants identified time allocation for individual subjects in the CAPS document as another factor inhibiting teaching and learning in Science and Mathematics. In corroboration, Matsepe and Maluleke (2019) mentioned that time impedes the smooth implementation of the CAPS document. Regarding this, School C's Physical Sciences teacher said:

The only problem we have with the CAPS is the time. Some sections we find that CAPS allocates ... ten hours, [but] we only spend three hours on [it] ... Other sections, they have two hours, we spend ten hours; so sometimes, the time allocation for the CAPS, we don't follow that...

In the view of School C's HOD, the time factor impacts negatively on curriculum coverage, making it difficult to complete the syllabus, except through extra classes:

Because, according to us, there is too much work to be covered, where there is no time. You'll find that, according to the curriculum, we have to cover this section in the first term, but there is not enough time to do that. Unless we do extra lessons; and there are some challenges with extra lessons also. 
Challenges caused by time allocation in the CAPS document are severe in schools across South Africa (Maharajh, Nkosi \& Mkhize, 2016; Matsepe, \& Maluleke, 2019), and specific to the sciences, where inquiry-based learning in the laboratory requires more time (Gudyanga, \& Jita, 2019). This is not to ignore pertinent factors that are impeding policy-implementation processes such as teacher experience and professional identities. Oguoma, Jita and Jita (2019) particularly noted that less experienced teachers are more likely to be distressed and challenged when implementing the CAPS document.

However, qualified teachers also struggle to implement the CAPS document effectively due to time constraints. School A's principal explained: "[We] have got very good teachers that are qualified ... the only problem is the time factor ... with Physical Science, especially Grade 11, where the teachers are struggling to get through the curriculum."

Seemingly, positive changes are possible within the South African education system, especially the improvement of curriculum coverage, by identifying and resolving challenges teachers encounter daily to ensure school improvement (see Marishane, 2016; Mowat, 2019). Pillay's suggestion indicates that the CAPS document is not so gloomy after all, a thought that corresponds with positive sentiments echoed by some research participants. For example, School B's Mathematics teacher expressed satisfaction with the CAPS document in the following words:

I don't have any problems with CAPS; it's, like, now aligned from the simple to the complex, compared to the years before; it [previous curriculum statements] was not organised. With CAPS, we can see that the topics there are developing from Grade 11; Grade 12 there are enforcing, there [are] no problems with those topics.

Similarly, the Mathematics teacher of School D argued that unlike the past years, the antecedents of CAPS were not organised, but that the current situation is different:

... now, you can see that the topics are developed from Grades 10, 11, and 12. They [DBE] are reinforcing, so it is like a ladder; you are starting from the simple, going up to the more complex ... those topics, there is no problem with them, they are okay ... it is just that they [the content] were not included, when we did them [topics] long ago; it is only now we go read and teach them.

Although these positive commentaries came mostly from Mathematics teachers, it indicates that when the CAPS document is simplified for easy implemented and communicated effectively, many more teachers may appreciate the strengths of the curriculum and how it is organised.

\subsection{The Role of the District Education Office}

Despite the commendable role of district officials in enhancing curriculum implementation, there have been reports of a lack of support and poor visibility. Research participants recounted a deficiency in terms of professional development opportunities and unsatisfactory execution of supervisory role by district officials. For example, the Physical Sciences teacher in School B bemoaned that district officials are rarely available, and visit mostly when learner results are released. The teacher said: "... it only becomes mandatory to meet with the district office when marks for Mathematics and Science are published." In corroboration, Nkambule and Amsterdam (2018) mentioned that teachers in some South African districts do not receive the kind of support they need from district officials, with negative repercussions on teaching and learning. This aligns with an earlier study by Mavuso (2013), reporting on a lack of cooperation between district officials and schools in a particular district. 
Similarly, School A's Mathematics teacher casted doubts on the supervisory role of district officials who make contact mostly with the HODs and principals, while side-lining the teachers, those who actually need their support. This teacher said: "I don't want to comment much with the district on the supervising because when they come, they go to the principal or HOD..." Additionally, Nkambule and Amsterdam (2018, p. 8) noted that district officials visit schools mostly to ensure compliance with what policy expects from them, and sparingly engage in support activities.

Furthermore, the Physical Sciences teacher for School D indicated that the district officials in some instances come to the school to assess their material needs, promising to assist, but do not always come back to deliver on their promises (see Nkambule, \& Amsterdam, 2018). Bantwini and Moorosi (2018a) corroborated this assertion by highlighting the lack of visibility, whereby district officials fail to respond or follow up to provide the services that schools expect of them. School A's Mathematics teacher tapped into the conversation of poor visibility of district officials by saying that "the subject advisor said that if you [we] have a problem in this topic, [we should] email them so that they can see their programmes ... [to] come and teach that topic ... but it's rare".

To echo the impact of district officials' poor visibility, the HOD for School C reemphasised the importance of their availability for the teaching and learning process:

We expect them to come to school during the visits which they have planned to find out from us what the challenges are, and maybe to go with us in class and see the situation in the classroom. So, if they could be with us maybe on the day that they say they'll be coming and also for us to show them the challenges - especially in terms of the syllabus coverage ...

Bantwini and Diko (2011) agreed that district officials were battling to provide services such as professional development opportunities to meet up with the demands of new educational reforms, monitoring the reform-implementation process, and providing ongoing support for individual teachers in schools. However, Bantwini and Diko (2011) argued that lack of commitment by district officials resonates with their lack of capacitation and sometimes overwhelming expectations, which restrict them from attending to the many schools assigned to each official, a view supported by Bantwini and Moorosi (2018b). School C's HOD corroborated that " $[t]$ hey sometimes come once in a quarter. Maybe they have a lot of work or many schools to attend to ..."

It emerged that district officials sometimes adopt a selective approach based on their assessment of a school's wellbeing. School B's HOD explained:

She is not very active here. She says that she needs to help other schools in other areas and that's where she goes, not coming here to see things [to provide support] because things are going okay. We've got the highest average in the district, so why should she come here?

The selective approach, however, did not take into consideration the needs of the concerned schools in general and teachers in particular. Similarly, School B's Physical Sciences teacher corroborated the selective approach of the district office. When asked about the role of the district office in enhancing the teaching and learning of Science and Mathematics, this teacher said: "Not with our school specifically. No. In her defence, she does workshops but with schools that have a pass mark that's not as high as ours." Furthermore, School C's HOD elaborated on the lack of support from the district office despite them needing support: "Yeah, well, subject advisors usually don't come to school often. 
Yes, I can say that we miss their support." The remark of School C's HOD directly criticises the selective approach adopted by district officials.

\subsection{Professional Development}

Teacher professional development plays a major role in enhancing teaching and learning in Science and Mathematics in all school contexts (Tsakeni, \& Jita, 2019; Yow, \& Lotter, 2016). Liljenberg and Wrethander (2020) and Marishane (2016) suggested that teacher professional development leads to effective curriculum implementation for school improvement. However, findings indicate that professional development opportunities are either not available, few, or do not meet the needs of the participating teachers. School B's Physical Sciences teacher elaborated on not participating in professional development workshops despite the desire to do so:

No professional development workshop. I've never received an invitation or a notice of such a workshop ... Ever since I came here, I haven't received anything from the department ... I am willing to go to such workshops if I am allowed.

Because some professional development workshops do not meet the needs of the teachers, some schools tended to resort to in-school development programmes. School A's HOD for Science elaborated on school-based professional development opportunities:

We go to workshops that are not always worthwhile, so that is why we did a few in-house workshops, because we could focus on what we have, the learners we are teaching, and what we can teach them specifically.

Jacobs, Gordon and Solis (2016) and Moswela and Kgosidialwa (2019) corroborated the inadequacy of professional development opportunities for teachers. Based on teachers' desire for the acquisition of relevant skills, some participants pleaded for goal-driven professional development workshops that are intense and would target their specific needs holistically (see Jacobs, Gordon \& Solis, 2016). Liljenberg and Wrethander (2020) noted that such goal-driven workshops will lead to skills maximisation. School C's HOD said:

They should consider that teachers are the ones who are going to teach ... you can't be workshopped for two days and they say you are expected to teach the learners. That is what the challenge is ... you can't conduct a workshop on one day on something to be taught for the rest of the year.

The Mathematics and Science HOD for School $\mathrm{C}$ expatiated on the negative implications of a lack of relevant professional workshops on curriculum delivery:

Those who are not willing to work ... are frustrated by the syllabus ... Because teaching something that you don't understand also is a challenge. You find that a teacher that is supposed to teach this topic, and he is not so clear about that topic - that is where the challenges come ... If there is a change in the curriculum, the people concerned will make sure that the teachers are thoroughly trained. Because we can't blame teachers that are expected to [teach] something and they don't know.

According to Nkambule and Amsterdam (2018), existing conditions in many South African schools necessitate ongoing professional development to assist teachers to perform their duties diligently. Furthermore, the Physical Sciences teacher for School B described workshops attended as not in depth enough to meet their intended purpose: 
Usually, the facilitator goes through certain sections whereby she finds ... what we might still need to develop in. It's not like a workshop; it's only mentioning [that] in this section you must pay attention to this; it's quick and it's not a whole thing.

Besides, teachers and HODs as curriculum implementers do not receive the necessary professional development and support needed to perform their duties holistically, thereby negatively affecting school improvement agendas (Liljenberg, \& Wrethander, 2020). School C's HOD highlighted the lack of orientation:

... we did not even go for the training for the HODs ... We were just put as HOD, and then you are just told you are in charge of these subjects ... from there we had to move on our own. There was no formal introduction as to what is supposed to be done - the district people did not do that.

The lack of a stated policy that makes the induction of new teachers and HODs mandatory downplays its importance in school improvement (Liljenberg, \& Wrethander, 2020; Ntsoane, 2018). Undeniably, the lack of proper training and indication for HODs is an ongoing problem in many South African schools. Tapala, Van Niekerk and Mentz $(2020$, p. 13) reported the negative implications of this phenomenon on curriculum delivery. It was affirmed that many teachers and HODs involved in the current study learned on the job and relied more on in-school professional development opportunities. School B's Physical Sciences teacher is an example. Similarly, School B's HOD talked of inadequate professional development opportunities: “... as far as I can remember, I went there once or twice; I don't think it's really necessary to go there." School C's HOD further elaborated on dissatisfaction with the nature of professional development opportunities which are not ongoing, with detrimental consequences on curriculum delivery:

I don't think they are doing enough ... There are workshops, but, for me, they are not enough, because you find that HODs are being called maybe at the beginning of the year to say this is actually what is expected of you: we expect one, two, three, four. You need to report on this, and this, and this ... then it's quiet, and they expect results, you see ... I think they are not doing enough; maybe more could still be done.

Without adequate training, HODs are unlikely to possess the capacity to effectively execute their duties as instructional leaders (Du Plessis, 2016). A study by Tapala, Van Niekerk and Mentz (2020, p. 13) identified the lack of professional development as the single most mentioned barrier by HODs, indicating that the problem is persistent and ongoing in some South African school districts, needing urgent attention.

\subsection{Learner-related Challenges}

Regarding learner-related challenges, what emerged include distance between learners' homes and the schools, and many learners choosing Science and Mathematics even though they lack the capabilities to cope with the subjects. The distance between learners' homes resonated in Schools B and C. In School C, this affected the organising of extra classes, especially in the mornings, as the HOD elaborated:

If you invite learners to come in the morning - not all of them stay near the school some come from afar. They use [public] transport in the mornings. So they have to be here early. It's a challenge because they have to leave their places as early as six o'clock in the mornings, some as early as a quarter to six ... it's a challenge, so coming late becomes a challenge. 
This distance, culminating in what Hall (2019) considered physical-access trajectories, is likely to cause exclusion for learners living far from school without adequate transportation means.

Regarding learners' choice for Science and Mathematics despite lacking the passion and capabilities, two main factors influenced such decisions - the assumption of guaranteed employment after graduation and pressure from parents who prefer science subjects. The assumption of securing a job after graduation if learners choose Science and Mathematics creates teaching and learning challenges in the classroom. School B's Physical Sciences teacher expounded on this matter:

Learners who choose Science cannot do science. Many learners feel that having to take Science ... might take them somewhere once they reach university, but they do not have the ability or the passion for it ... parents forced [them] to take Science - those are the biggest challenges.

However, schools do put the necessary steps in place to ameliorate such challenges. The Physical Sciences teacher for School C explained the route taken by the school:

Usually, those parents that come to parents' meetings, we just talk to them and make them understand that the learner's passion is not in science and if they still agree that the child should continue with Science, then we inform them about the extra classes as well as extra help for their children, to make them excel in the subject.

The teachers' tone is an indication that teachers make attempts to persuade parents and but do not have the powers to prevent learners from engaging in subjects they or their parents choose for them, even though they may not have the capabilities to pursue them.

\subsection{Resources}

It was found that the lack of resources impedes teaching and learning opportunities for Science and Mathematics. These include human resources, and physical resources in terms of inadequate laboratories for practical work, and technology. The deputy principal of School C highlighted teacher shortage as a major challenge hindering curriculum delivery in Science and Mathematics:

Unfortunately, we do not have enough educators for Science. For Science, there are four educators, but only two [permanent], including myself. The other two are temporary. We had three other teachers that ... got a promotion to other schools. They were Science teachers ... most of the educators that are here ... Some of them did not even major in Science; they did Maths, pure Maths. Therefore, it is Maths, so they do teach Maths and Maths Lit ... that's challenging.

The shortage of qualified Science and Mathematics teachers is neither new nor limited to South Africa (Dolph, 2017; John, 2019; Mlambo, \& Adetiba, 2020; Van Rooij, Fokkens-Bruinsma \& Goedhart, 2019), with negative implications for Science and Mathematics teaching and learning, thus impeding curriculum implementation.

However, the situation was different in the well-resourced School A. It did not experience a shortage of qualified teachers; rather, the school has enough staff, with a reasonable teacher-learner ratio conducive for teaching and learning. The School A principal painted a positive picture of the teacher-learner ratio at the school, and explained how they managed to obtain enough money to pay the salaries of their huge staff component without overstretching parents:

We have 104 teachers; many are paid by SGB [school governing body], we don't want classes bigger than 30, that's why it cost lots of money, that is the bigger part of our 
budget ... there are those [parents] who get the subsidy; if they cannot afford it, we have got [a] scale. Some parents are paying school fees, we get donations, and we have fundraising.

Undeniably, teacher-learner ratio has a significant effect on curriculum delivery and school improvement (Khechane, Makara \& Rambuda 2020). A high learner-teacher ratio puts a strain on resources and restricts teachers from catering for individual learner needs. Zenda (2020) argued that a high learner-teacher ratio creates discipline problems in the classroom, and prevents teachers from engaging in meaningful practical activities important in the sciences.

Furthermore, laboratories have positive impacts on Science teaching, but learners in schools with inadequate resources are missing such opportunities (Jones, Chang, Carter \& Roden, 2019). The effects of the lack of laboratory spaces in the teaching of Science and Mathematics were articulated by the deputy principal of School D: "It is not easy without the lab and they [teachers] cannot go ask for permission to use laboratories at other schools; it's not easy ..." School C's deputy principal and HOD raised similar concerns. The HOD explained how overcrowding exacerbated the challenge of inadequate laboratory spaces:

Only one lab for Life Sciences and Physical Sciences - that's a challenge. Uh, I can say the support is minimum ... the challenge is the large number of classes that we are having ... for instance, in one class, the maximum number of learners is 46 . That is the major challenge, because we don't have a Life Sciences Lab. Initially, it was supposed to be the Physical Sciences Lab, and Life Sciences was supposed to have its lab, but because it is only one lab, it is used both by Physical Sciences and Life Sciences, and mostly Physical Sciences teachers use it. Most of the materials in the lab are for Physical Sciences.

Additionally, in School D, the challenge concerning limited laboratory access and inadequate materials hindered practical work. Mostly, learners doing Electrical Engineering and Chemistry had enough laboratory access. This leads to the exclusion of engaging in practical work in other sciences subjects, despite practical work playing a major role in improving learners' performance in Science (Festile, 2017). School D's Mathematics teacher explained:

There [are] no labs. Although we have mobile labs ... it's very difficult to demonstrate [to] the learners because the school does not have the lab; it's very hard to demonstrate ... because many learners, they don't do it, materials are limited. Yes, enough for Chemistry ... [However,] when it comes to the Physics part of it...

With the lack of laboratories for Mathematics, School D's HOD stated its case by indicating the possible benefits to accrue if Mathematics learners had access to a laboratory. According to the HOD, the school had been nursing the idea of having a Mathematics laboratory, but was restricted financially. Also, participants highlighted that inadequate technological resources limited the enhancement of teaching and learning opportunities in Science and Mathematics. School C's deputy principal said: "Unfortunately, we don't have whiteboards ... Lack of technology to facilitate practical work ... we don't have projectors. We are still using chalkboards ..."

According to School D's deputy principal, some tablets were provided, but they were limited to the Grade 12 learners. These devices were preloaded with past question papers to enable learners to revise in preparation for the matric examinations and not for teaching purposes. The deputy principal said that "[t]he Grade $12 \mathrm{~s}$ received tablets ... there were no tablets for educators ... in the tablets is 
previous question papers ... and some exemplar papers for learners to use for revision. It's not basically for teaching ..."

From the narratives of the participant, although the tablets were provided, they did not in practical terms contribute to the teaching and learning process.

\section{Conclusions and Implications}

The paper explored issues and challenges affecting school improvement opportunities for Science and Mathematics in selected South African high schools. Based on the narrative that school improvement is the currency in educational settings, the paper was intended to understand factors that obstruct efforts put in place by teachers and schools to actualise this dream. We used a systems leadership lens given its affordances to acknowledge contextual-setting factors and a holistic approach to view their influence on school improvement as emanating from several stakeholders in the system. Findings indicate that the implementation of CAPS, the role of the district, professional development, learnerrelated challenges, and resources affected school improvement efforts, especially in previously disadvantaged schools. The paper recommends adequate capacitation and strengthening of the system's leadership through the deployment of sufficient district officials with the sole purpose of providing support to schools, to enhance the process of teaching and learning. Also, the DBE needs to activate its monitoring mechanisms to ensure that they function regularly to determine how schools cope with policy implementation and to identify possible challenges and provide relevant assistance to enhance smooth teaching and learning.

\section{Acknowledgements}

This study was supported by SANRAL in South Africa.

\section{References}

Aldaihani, S. G. (2020). Distributed Leadership Applications in High Schools in the State of Kuwait from Teachers' Viewpoints. International Journal of Leadership in Education, 23(3), 355-370. https://doi.org/10.1080/13603124.2018.1562096

Bantwini, B. D., \& Diko, N. (2011). Factors Affecting South African District Officials' Capacity to Provide Effective Teacher Support. Creative Education, 2(3), 226-235. https://doi.org/10.15700/saje.v38n3a1577

Bantwini, B. D., \& Moorosi, P. (2018a). School District Support to Schools: Voices and Perspectives of School Principals in a Province in South Africa. International Journal of Leadership in Education, 21(6), 757-770. https://doi.org/10.1080/13603124.2017.1394496

Bantwini, B. D., \& Moorosi, P. (2018b). The Circuit Managers as the Weakest Link in the School District Leadership Chain! Perspectives from a Province in South Africa. South African Journal of Education, 38(3), 1-9. https://doi.org/10.15700/saje.v38n3a1577

Bayeni, S. D., \& Bhengu, T. T. (2018). Complexities and Contradictions in Policy Implementation: Lived Experiences of Three School Principals in South Africa. SAGE Open, 8(3), 1-12. https://doi.org/10.1177/2158244018792037

Brunetti, A., Büchel, K., Jakob, M. S., Jann, B., Kühnhanss, C., \& Steffen, D. (2020). Teacher Content Knowledge in Developing Countries: Evidence from a Math Assessment in El Salvador. (Working Paper No. 2005). Department of Economics, University of Bern. 
Bush, T., \& Glover, D. (2016). School Leadership and Management in South Africa. International Journal of Educational Management, 30(2), 211-231. https://doi.org/10.1108/IJEM-07-2014-0101

Clothey, R., Mills, M. \& Baumgarten, J. (2010). A closer look at the impact of globalization on science education. Cultural Studies of Science Education, 5, 305-313. http://dx.doi.org/10.1007/s11422-010-9258-6

Dagnew, A. (2017). The Practice and Challenges of Distributed Leadership at Some Selected Schools of Debark District: Ethiopia. Journal of Education, Society and Behavioural Science, 20(3), 1-10. https://doi.org/10.9734/BJESBS/2017/32436

Daya, A., \& Laher, S. (2020). Exploring the Influence of Educators' Access to and Attitudes towards Educational Technology on the Use of Educational Technology in Johannesburg Schools. Africa Education Review, 17(1), 159-180. https://doi.org/10.1080/18146627.2018.1490154

De Freitas, G., \& Spangenberg, E. D. (2019). Mathematics Teachers' Levels of Technological Pedagogical Content Knowledge and Information and Communication Technology Integration Barriers. Pythagoras, 40(1), 1-13. https://doi.org/10.4102/pythagoras.v40i1.431

Dixon, K. (2020). Searching for Mermaids: Access, Capital, and the Digital Divide in a South African Rural Primary School. In E. Morrell, \& J. Rowsell (Eds.), Stories from Inequity to Justice in Literacy Education: Confronting Digital Divides (pp. 15-33). New York: Routledge.

Dolph, D. (2017). Challenges and Opportunities for School Improvement: Recommendations for Urban School Principals. Education and Urban Society, 49(4), 363-387. https://doi.org/10.1177/0013124516659110

Donaldson, M. L. \& Weiner, J. (2017). The Science of Improvement: Responding to Internal and External Challenges in a Complex School Environment. Journal of Cases in Educational Leadership, 20(3), 65-75. https://doi.org/10.1177/1555458917705412

Du Plessis, A. (2016). South African Heads of Department on Their Role in Teacher Development: Unexpected Patterns in an Unequal System. In N. Popov, C. Wolhuter, J. Kalin, G. Hilton, J. Ogunleye, \& E. Niemczyk (Eds), Education Provision to Every One: Comparing Perspectives from Around the World (pp. 113-119). Sofia, Bulgaria: Bulgarian Comparative Education Society (BCES).

Du Plessis, P., \& Mestry, R. (2019). Teachers for Rural Schools: A Challenge for South Africa. South African Journal of Education, 39(4), 1-9. https://doi.org/10.15700/saje.v39ns1a1774

Festile, R. M. (2017). The Influence of Practical Work in the Teaching and Learning of Acids, Bases and Neutrals in Natural Sciences (Unpublished Master's Thesis). University of the Western Cape: Cape Town. http://etd.uwc.ac.za/handle/11394/5921

Fullan, M. (2005), Leadership and Sustainability: System Thinkers in Action, Corwin Press andOntario Principals' Council, Thousand Oaks, CA.

Gaillard, C. (2019). Finding the Missing Variables: A Systematic Review of Mathematics Improvement Strategies for South African Public Schools. South African Journal of Education, 39(3), 1-9. https://doi.org/10.15700/saje.v39n3a1582

Gawlik, M. A. (2015). Shared Sense-making: How Charter School Leaders Ascribe Meaning to Accountability. Journal of Educational Administration, 53(3), 393-415. https://doi/abs/10.1108/JEA-08-2013-0092

Govender, L. V. (2008). Teachers' Participation in Policy Making: The Case of the South African Schools Act. (Unpublished Doctoral Thesis). University of the Witwatersrand, Johannesburg, South Africa. https://core.ac.uk/reader/39665816

Gudyanga, R., \& Jita, L. C. (2019). Teachers' Implementation of Laboratory Practicals in the South African Physical Sciences Curriculum. Issues in Educational Research, 29(3), 715-731. https://www.iier.org.au/iier29/gudyanga-abs.html 
Hallinger, P. \& Heck, R.H. 2010. Collaborative leadership and school improvement: Understanding the impact on school capacity and student learning. School Leadership and Management, 30(2), 95-110. https://doi.org/10.1080/13632431003663214

Hall, K. (2019). Children's Access to Education. In: M. Shung-King, L. Lake, D. Sanders, \& M. Hendricks (Eds.), South African Child Gauge 2019: Child and Adolescent Health - Leave No One Behind (240-247). Children's Institute: University of Cape Town.

Heffernan, A. (2018). The Influence of School Context on School Improvement Policy Enactment: An Australian Case Study. International Journal of Leadership in Education, 21(6), 621-632. https://doi.org/10.1080/13603124.2018.1463461

Jacobs, J., Gordon, S. P., \& Solis, R. (2016). Critical Issues in Teacher Leadership: A National Look at Teachers' Perception. Journal of School Leadership, 26(3), 374-406. https://doi.org/10.1177/105268461602600301

John, M. (2019). Physical Sciences Teaching and Learning in Eastern Cape Rural Schools: Reflections of Preservice Teachers. South African Journal of Education, 39(4), 1-12. https://doi.org/10.15700/saje.v39ns1a1660

Jones, A., Chang, A., Carter, R., \& Roden, W. (2019). Impacts of Hands-on Science Curriculum for Elementary School Students and Families Delivered on a Mobile Laboratory. Journal of Stem Outreach (JOS), 2(1), 1-12. https://doi.org/10.15695/istem/v2i1.02

Khechane, N. C., Makara, M. C., \& Rambuda, A. M. (2020). Primary Mathematics Teachers' Assessment Practices in the Context of the Integrated Primary Curriculum in Lesotho. African Journal of Research in Mathematics, Science and Technology Education, 24(1), 42-52. https://doi.org/10.1080/18117295.2020.1735672

Kivunja, C., \& Kuyini, A. B. (2017). Understanding and Applying Research Paradigms in Educational Contexts. International Journal of Higher Education, 6(5), 26-41. https://eric.ed.gov/?id=EJ1154775

Leithwood, K., Harris, A., \& Hopkins, D. (2020). Seven Strong Claims about Successful School Leadership $\begin{array}{llll}\text { Revisited. School Leadership \& } & \text { 5 }\end{array}$ https://doi.org/10.1080/13632434.2019.1596077

Leoisa, M., \& Jita, L. C. (2020). Meaning Behind the Words: Physical Science Teachers' Pedagogic Reform Interpretation in Lesotho. Southern African Association for Research in Mathematics, Science and Technology Education, 246, 14-16 January. Eastern Cape, South Africa.

Liljenberg, M., \& Wrethander, M. (2020). Leadership for School Improvement: Linking Learning to Leading Over Time. Professional Development in https://doi.org/10.1080/19415257.2020.1752288

Maharajh, L. R., Nkosi, T., \& Mkhize, M. C. (2016). Teachers' Experiences of the Implementation of the Curriculum and Assessment Policy Statement (CAPS) in Three Primary Schools in KwaZulu Natal. Africa's Public Service Delivery \& Performance Review, 4(3), 371-388. https://doi.org/10.4102/apsdpr.v4i3.120

Makoelle, T. M., \& Sabata, S. (2019). Action Research: Magnifying Curriculum Development at Classroom Level. In: T. M. Makoelle (Ed.), Action Research in South African Education: A Critical Praxis (pp. 41-52). African Sun Media.

Marishane, M. R. (2016). Leadership and Context Connectivity: Merging Two Forces for Sustainable School Improvement. In: N. Popov, C. Wolhuter, J. Kalin, G. Hilton, J. Ogunleye, \& E. Niemczyk (Eds.), Education Provision for Everyone: Comparing Perspectives from Around the World, Vol. 14(1), (pp. 163-169). BCES, BCES Conference Books. https://eric.ed.gov/?id=ED568098

Matsepe, D., \& Maluleke, M. (2019). Constraints to Optimal Implementation of Curriculum and Assessment Policy Statement (CAPS) in the North West Province in South Africa. Ubuntu: Journal of Conflict 
Tsakeni, M., Munje, P. \& Jita, L., (2021). Issues and challenges influencing school improvement opportunities for science and mathematics. Cypriot Journal of Educational Science. 16(3), 1300-1318. https://doi.org/10.18844/cjes.v16i3.5853
Transformation,
8 (Special
Issue
1),
177-195.

https://doi.org/10.31920/2050-4950/2019/sin1a10

Mavuso, M. P. (2013). Education District Office Support for Teaching and Learning in Schools: The Case of Two Districts in the Eastern Cape. (Unpublished Doctoral Thesis). University of Fort Hare, South Africa. Retrieved from http://libdspace.ufh.ac.za/handle/20.500.11837/460

Mitchell, C., \& Sackney, L. (2016). School Improvement in High-capacity Schools: Educational Leadership and Living-systems Ontology. Educational Management Administration \& Leadership, 44(5), 853-868. https://doi.org/10.1177/1741143214564772

Mlambo, V. H., \& Adetiba, T. C. (2020). The Brain Drain of Teachers in South Africa: Identifying the Dynamics of Its Push Factors. e-Bangi, Journal of Social Sciences and Humanities, 17(1), 152-164. Retrieved from http://ejournal.ukm.my/ebangi/article/view/37504/10210

Molapo, M. R., \& Pillay, V. (2018). Politicising Curriculum Implementation: The Case of Primary Schools. South African Journal of Education, 38(1), 1-9. https://doi.org/10.15700/saje.v38n1a1428

Moswela, B. \& Kgosidialwa, K. (2019). Leadership and School Success: Barriers to Leadership in Botswana Primary and Secondary Schools. Educational Management Administration \& Leadership, 47(3), 443-456. https://doi.org/10.1177/1741143217739355

Mouton, N., Louw, G. P., \& Strydom, G. (2013). Critical Challenges of the South African School System. International Business \& Economics Research Journal (IBER), 12(1), 31-44. https://doi.org/10.19030/iber.v12i1.7510

Mowat, J. G. (2019). 'Closing the Gap': Systems Leadership is No Leadership at All Without a Moral Compass - A Scottish Perspective. School Leadership \& Management, 39(1), 48-75. https://doi.org/10.1080/13632434.2018.1447457

Murray, M. (2016). Does Poor Quality Schooling and/or Teacher Quality Hurt Black South African Students Enrolling for a Degree at the University of KwaZulu-Natal? PLUS ONE, 11(4), 1-11. https://doi.org/10.1371/journal.pone.0153091

Mwapwele, S. D., Marais, M., Dlamini, S., \& Van Biljon, J. (2019). Teachers' ICT Adoption in South African Rural Schools: A Study of Technology Readiness and Implications for the South Africa Connect Broadband Policy. The African Journal of Information and Communication, 24, 1-21. http://dx.doi.org/10.23962/10539/28658

Naicker, S. R., \& Mestry, R. (2013). Teachers' reflections on Distributive Leadership in Public Primary Schools in Soweto. South African Journal of Education, 33(2), 1-15. https://doi.org/10.4018/978-1-4666-6591$\underline{0 . \operatorname{ch} 013}$

Nkambule, G., \& Amsterdam, C. (2018). The Realities of Educator Support in a South African School District. South African Journal of Education, 38(1), 1-11. https://doi.org/10.15700/saje.v38n1a1433

Ntsoane, L. D. (2018). The Role of School Management Team Members in the Induction of Novice Teachers in Rural Schools. (Unpublished Doctoral Dissertation). University of Pretoria. https://repository.up.ac.za/handle/2263/65459

Ogegbo, A.A., Gaigher, E. \& Salagaram, T. (2019). Benefits and Challenges of Lesson Study: A Case of Teaching Physical Sciences in South Africa. South African Journal of Education, 39(1), 1-9. https://doi.org/10.15700/saje.v39n1a1680

Oguoma, E., Jita, L., \& Jita, T. (2019). Teachers' Concerns with the Implementation of Practical Work in the Physical Sciences Curriculum and Assessment Policy Statement in South Africa. African Journal of Research in Mathematics, Science and Technology Education, 23(1), 27-39. https://doi.org/10.1080/18117295.2019.1584973 
Sebastian, J., Huang, H., \& Allensworth, E. (2017). Examining Integrated Leadership Systems in High Schools: Connecting Principal and Teacher Leadership to Organizational Processes and Student Outcomes. School Effectiveness and School Improvement, 28(3), 463-488. https://doi.org/10.1080/09243453.2017.1319392

Robinson, N. (2019, 9 January). Poor Quality Teachers are Holding Back SA's Education System. BizNews. Retrieved from https://www.biznews.com/sa-investing/2019/01/09/poor-quality-teachers-holding-backsa-education-system

Selod, H. \& Zenou, Y. (2003). Private Versus Public Schools in Post-apartheid South African Cities: Theory and Policy Implications. Journal of Development Economics, 71(2), 351-394. http://dx.doi.org/10.1016/S03043878(03)00033-6

Shaked, H., \& Schecther, C. (2020) Systems Thinking Leadership: New Explorations for School Improvement. Management in Education, 34(3), 107-114. https://doi.org/10.1177/0892020620907327

Supovitz, J. A., D'Auria, J., \& Spillane, J. P. (2019). Meaningful and Sustainable School Improvement with Distributed Leadership. Consortium for Policy Research in Education. Retrieved from https://repository.upenn.edu/cpre researchreports/112/

Swanepoel, C. (2009). A Comparison Between the Views of Teachers in South Africa and Six Other Countries on Involvement in School Change. South African Journal of Education, 29(4), 461-474. https://doi.org/10.15700/saje.v29n4a291

Taahayadin, F., \& Daud, Y. (2018). School Culture and School Improvement Challenges in Kedah. Journal of Business and Management, 20(6), 25-30. Retrieved from http://www.iosrjournals.org/iosrjbm/papers/Vol20-issue6/Version-1/D2006012530.pdf

Taole, M. J. (2013). Exploring Principals' Role in Providing Instructional Leadership in Rural High Schools in South $\begin{array}{llllll}\text { Africa. Studies of Tribes and } & \text { Tribals, }\end{array}$ https://doi.org/10.1080/0972639X.2013.11886668

Tapala, T. T., Van Niekerk, M. P., \& Mentz, K. (2020). Curriculum Leadership Barriers Experienced by Heads of Department: A Look at South African Secondary Schools. International Journal of Leadership in Education, 1-18. https://doi.org/10.1080/13603124.2020.1740796

Thaba-Nkadimene, K. L., \& Mmakola, S. D. (2019). Examining the Performance of Teacher Graduates from Limpopo Rural University. South African Journal of Higher Education, 33(5), 169-181. https://doi.org/10.20853/33-5-3596

Tsakeni, M., \& Jita, L. (2019). School Leadership Practices for Science and Mathematics in High-stakes Testing Environments: An Integrated School Leadership Approach. Perspectives in Education, 37(2), 98-109. https://doi.org/10.18820/2519593X/pie.v37i2.7

Van Rooij, E. C. M., Fokkens-Bruinsma, M., \& Goedhart, M. (2019). Preparing Science Undergraduates for a Teaching Career: Sources of Their Teacher Self-efficacy. The Teacher Educator, 54(3), 270-294. https://doi.org/10.1080/08878730.2019.1606374

Venkat, H., Askew, M., Morrison, S., \& Abdulhamid, L. (2019). Shifts in Early Number Learning in South Africa. In 43rd Conference of the International Group for the Psychology of Mathematics Education, pp. 422-429, 712 July, Pretoria, South Africa.

Waller, P. P., \& Maxwell, K. L. (2017). Mathematics Teachers' Perceptions of Resources and Curriculum Availability in Post-apartheid Schooling. International Journal of Science and Mathematics Education, 15(4), 741-757. https://doi.org/10.1007/s10763-016-9713-2

Yin, R. K. (2018). Case study research and applications: Design and methods (6th ed.). Los Angeles, CA: Sage. 
Tsakeni, M., Munje, P. \& Jita, L., (2021). Issues and challenges influencing school improvement opportunities for science and mathematics. Cypriot Journal of Educational Science. 16(3), 1300-1318. https://doi.org/10.18844/cjes.v16i3.5853

Yow, J. A., \& Lotter, C. (2016). Teacher Learning in a Mathematics and Science Inquiry Professional Development Program: First Steps in Emergent Teacher Leadership. Professional Development in Education, 42(2), 325351. https://doi.org/10.1080/19415257.2014.960593

Zenda, R. (2020). Impact of the Learner-Educator Ratio Policy on Learner Academic Achievement in Rural Secondary Schools: A South African Case Study. Africa Education Review, 17(3), 1-19. https://doi.org/10.1080/18146627.2019.1588748 